Wahyuni, I. dan Munthe, YG.: Pengaruh Model Pembelajaran Kooperatif Tipe Two Stay Two Stray (TSTS) Terhadap Hasil Belajar Siswa Pada Materi Listrik Dinamis Pada Siswa SMA.

\title{
PENGARUH MODEL PEMBELAJARAN KOOPERATIF TIPE TWO STAY TWO STRAY (TSTS) TERHADAP HASIL BELAJAR SISWA PADA MATERI LISTRIK DINAMIS PADA SISWA SMA
}

\author{
Ida Wahyuni dan Yanty Geulora Munthe \\ Program Studi Pendidikan Fisika FMIPA Unimed \\ yantymunthe@gmail.com
}

\begin{abstract}
Abstrak. Penelitian ini bertujuan untuk mengetahui pengaruh penggunaan model pembelajaran Kooperatif Tipe Two Stay Two Stray terhadap hasil belajar siswa pada materi Listrik Dinamis di kelas X SMA. Jenis penelitian ini adalah quasi eksperimen dengan desain penelitian adalah Two Group Pretestpostest Design. Populasi penelitian seluruh siswa kelas X SMA Negeri 3 Tebing Tinggi yang terdiri 9 kelas. Sampel penelitian diambil 2 kelas yang ditentukan dengan teknik cluster random sampling yaitu kelas X-9 sebagai kelas eksperimen dan kelas X-8 sebagai kelas kontrol. Untuk menguji hipotesis digunakan uji t setelah uji prasyarat dilakukan yaitu uji normalitas dan uji homogenitas. Dari hasil penelitian nilai rata-rata pretes kelas eksperimen adalah 36,30 dan kelas kontrol 27,90. Untuk data pretes, pada pengujian normalitas di kelas eksperimen dengan $\mathrm{L}_{\text {hitung }}=0,1378$ dan $\mathrm{L}_{\text {tabel }}=$ 0,1730, kelas kontrol dengan $\mathrm{L}_{\text {hitung }}=0,1368$ dan Ltabel $=0,1730$, diperoleh $\mathrm{L}_{\text {hitung }}<\mathrm{L}_{\text {tabel, }}$ maka data kedua kelas berdistribusi normal. Pada uji homogenitas diperoleh $F_{\text {hitung }}=1,68$ dan $F_{\text {tabel }}=1,90$ sehingga $F_{\text {hitung }}<F_{\text {tabel}}$, maka sampel berasal dari kelompok homogen. Setelah diberikan perlakuan, diperoleh rata-rata nilai postes kelas eksperimen 72,30 dengan $\mathrm{L}_{\text {hitung }}=0,1478$ dan Ltabel $=0,1730$ sedangkan pada kelas kontrol diperoleh rata-rata nilai postes 66,60 dengan $\mathrm{L}_{\text {hitung }}=0,1489$ dan $\mathrm{L}_{\text {tabel }}=0,1730$, diperoleh $\mathrm{L}_{\text {hitung }}<$ $\mathrm{L}_{\text {tabel, maka data kedua kelas berdistribusi normal. Pada uji homogenitas }}$ diperoleh $\mathrm{F}_{\text {hitung }}=1,38$ dan pada $\mathrm{F}_{\text {tabel }}=1,90$, sehingga $\mathrm{F}_{\text {hitung }}<\mathrm{F}_{\text {tabel }}$, maka kedua sampel berasal dari kelompok homogen. Hasil pengujian hipotesis diperoleh $t_{\text {hitung }}>t_{\text {tabel }}$ yaitu 2,326 $>2,006$ dengan $\alpha=0,05 \mathrm{dan} \mathrm{dk}=54$, maka Ha diterima yang berarti ada perbedaan akibat pengaruh model pembelajaran Kooperatif Tipe Two Stay Two Stray dengan model pembelajaran konvensional terhadap hasil belajar siswa pada materi Listrik Dinamis di kelas X SMA Negeri 3 Tebing Tinggi T.P 2012/2013.
\end{abstract}

Kata kunci: pembelajaran kooperatif tipe two stay two stray, hasil belajar, aktivitas belajar, persepsi siswa

\section{THE EFFECT OF COOPERATIVE LEARNING MODELS TYPE TWO STAY TWO STRAY (TSTS) TO STUDENTS RESULT ON DINAMIC ELECTRICITY ON SENIOR HIGH SCHOOL STUDENTS}

Ida Wahyuni and Yanty Geulora Munthe

Physics Education Program-State University of Medan yantymunthe@gmail.com 


\begin{abstract}
This study aimed to determine the effect of the use of cooperative learning model type Two Stay Two Stray toward student learning outcomes in the material in class $\mathrm{X}$ Dynamic Power SMA. The study was quasiexperimental research design was pretest-posttest Group Two Design. The study population was all students of class X SMA Negeri 3 Tebing Tinggi comprising 9 classes. Samples were taken 2 classes are determined by random cluster sampling technique that is grade $\mathrm{X}-9$ as an experimental class $\mathrm{X}$ and class- 8 as a control class. To test the hypothesis used the $t$ test after test done the prerequisite test for normality and homogeneity tests. From the research, the average value is 36.30 pretest experimental class and control class 27.90. For the data pre-test, the normality test in the experimental class $\mathrm{L}_{\text {tabel }}=$ 0.1378 and $\mathrm{L}_{\text {hitung }}=0.1730$, with a control class $\mathrm{L}_{\text {tabel }}=0.1368$ and $\mathrm{L}_{\text {hitung }}=$ 0.1730 , obtained $\mathrm{L}_{\text {hitung }}<\mathrm{L}_{\text {tabel}}$, then the two classes of data are normally distributed. In the homogeneity test is obtained $\mathrm{F}_{\text {hitung }}=1.68$ and $\mathrm{F}_{\text {(table) }}=1.90$ so $F_{\text {hitung }}<\mathrm{F}_{\text {tabel, }}$, the samples came from a homogeneous group. After being given the treatment, the average value obtained posttest experimental class 72.30 with $\mathrm{L}_{\text {hitung }}=0.1478$ and $\mathrm{L}_{\text {tabel }}=0.1730$ while the control class gained an average of 66.6 with $\mathrm{L}_{\text {hitung }}$ posttest values $=0.1489$ and $\mathrm{L}_{\text {tabel }}=0.1730$, obtained $\mathrm{L}_{\text {hitung }}<\mathrm{L}_{\text {tabel}}$, then the two classes of data are normally distributed. In the homogeneity test is obtained $F_{\text {hitung }}=1.38$ and at $F_{\text {tabel }}=1.90$, so $F_{\text {hitung }}$ $<\mathrm{F}_{\text {tabel}}$, then both samples come from a homogeneous group. Hypothesis testing results obtained $t_{\text {hitung }}>t_{\text {tabel }}$ is $2.326>2.006$ with $\alpha=0.05$ and $\mathrm{df}=$ 54 , then $\mathrm{Ha}$ is accepted which means that there are differences due to the influence of cooperative learning model type two stay two stray with conventional learning model for student learning outcomes in Dynamic Electrical material in class X SMA N 3Tebing Tinggi TP 2012/2013.
\end{abstract}

\title{
Keywords: cooperative learning type two stay two stray, study outcomes, study activities
}

\section{PENDAHULUAN}

Dampak positif perkembangan ilmu pengetahuan dan teknologi (IPTEK) saat ini dapat meningkatkan kualitas aspek kehidupan manusia. Banyak informasi yang diperoleh dan penggunaan teknologi yang dapat membantu pekerjaan manusia. Seiring dengan perkembangannya, sumber daya manusia yang memiliki kinerja dan potensi tinggi sangat dibutuhkan untuk mengendalikan perkembangan teknologi.

Salah satu upaya yang dapat dilakukan untuk mempersiapkan sumber daya manusia yakni melalui pendidikan. Pendidikan mampu menyiapkan manusia untuk manghadapi masa depan. Sumber daya manusia yang berintelek- tual, beriman dan bertanggungjawab akan mampu beradaptasi dengan perkembangan ilmu pengetahuan dan teknologi. Menurut jabaran UUD 1945 tentang pendidikan dituangkan dalam Undang-Undang No. 20 Tahun 2003. Pasal 3 menyebutkan, "Pendidikan nasional berfungsi mengembangkan kemampuan dan membentuk watak serta peradaban bangsa yang bermartabat dalam rangka mencerdaskan kehidupan bangsa, bertujuan untuk berkembangnya potensi peserta didik agar menjadi manusia yang beriman dan bertakwa kepada Tuhan Yang Maha Esa, berakhlak mulia, sehat, berilmu, cakap, kreatif, mandiri, dan menjadi warga negara yang demokratis serta bertanggung jawab. Berbagai cara dikembangkan 
untuk mengatasi masalah yang terjadi di dalam pendidikan, seperti lemahnya proses belajar dan pelaksanaan pembelajaran yang kurang maksimal. Proses pembelajaran pada mata pelajaran fisika adalah bagian dari sains (IPA) yang pada hakikatnya merupakan kumpulan pengetahuan, cara berpikir dan penyelidikan. Mata pelajaran Fisika bertujuan agar peserta didik memiliki kemampuan membentuk sikap positif terhadap fisika dengan menyadari keteraturan alam dan memupuk sikap ilmiah yaitu jujur, obyektif, terbuka, ulet, kritis dan dapat bekerjasama dengan orang lain.

Dalam pembelajarannya dewasa ini, fisika lebih banyak mempelajari teori/konsep dan latihan soal yang berkaitan dengan kejadian nyata dan juga dapat diaplikasikan dalam kehidupan sehari-hari. Banyak siswa yang menganggap bahwa fisika adalah pelajaran yang yang tidak menyenangkan. Kesulitan dalam menyelesaikan soal perhitungan menjadi masalah utama dalam proses pembelajaran. Menurut Leona (2011) sampai saat ini masih sering didengar ungkapan bahwa pelajaran fisika itu sulit, bahkan apabila siswa ditanya lebih lanjut tentang bentuk kesulitan yang dihadapi banyak siswa yang menjawab tidak tahu atau tidak jelas kesulitannya.

Hal ini sesuai dengan hasil observasi awal yang dilakukan peneliti di SMA Negeri 3 Tebing Tinggi. Berdasarkan angket yang diisi siswa yang berjumlah 32 orang, maka $71,80 \%$ menyatakan mata pelajaran fisika sangat sulit dan kurang menarik. Siswa berpendapat bahwa fisika identik dengan rumus-rumus dan perhitungan yang banyak, mereka tidak dapat menemukan konsep, mencari dan mengaplikasikannya dalam kehidupan sehari-hari, sehingga tujuan dari hasil pendidikan belum sesuai dengan apa yang diharapkan. Menghapal rumus tidak menjamin siswa bisa mengerjakan soal. Banyak siswa yang jarang bertanya kepada guru tentang materi yang kurang jelas dan kurangnya interaksi antarsiswa selama proses belajar.

Hasil angket kepada guru fisika kelas X SMA Negeri 3 Tebing Tinggi, Ibu Utami
Siregar, diperoleh data hasil belajar fisika siswa yang pada umumnya masih rendah yaitu ratarata 70 sedangkan Kriteria Ketuntasan Minimal (KKM) yang akan dicapai adalah 75. Sehingga dapat dikatakan nilai rata-rata siswa tidak mencapai kriteria yang diharapkan.

Proses belajar mengajar yang terjadi di kelas umumnya ditentukan oleh peran guru dan siswa sebagai individu-individu yang terlibat dalam proses tersebut. Cara guru menyampaikan pelajaran pada anak didik sedikit banyaknya mempengaruhi prestasi belajar siswa. Kemampuan serta kesiapan guru dalam mengajar memegang peranan penting bagi proses belajar mengajar. Hal ini menunjukkan adanya keterkaitan antara prestasi belajar siswa dengan metode mengajar yang digunakan guru.

Menurut Istarani (2012) model pembelajaran adalah rangkaian penyajian materi ajar yang meliputi segala aspek sebelum sedang dan sesudah pembelajaran yang dilakukan guru serta segala fasilitas yang terkait yang digunakan secara langsung atau tidak langsung dalam proses belajar mengajar. Penggunaan model pembelajaran yang dilakukan oleh guru dalam mengajarkan fisika kurang bervariasi. Model pembelajaran konvensional masih menjadi model pembelajaran yang utama digunakan oleh guru-guru dalam proses belajar mengajar sehingga siswa tidak dilibatkan secara penuh dalam proses belajar mengajar. Sehingga pada proses interaksi antar siswa tidak dapat terjadi karena hanya berpusat pada guru.

Dalam upaya mengatasi kebosanan siswa dalam belajar fisika dan meningkatkan hasil belajar diantaranya adalah dengan menerapkan model pembelajaran yang bervariasi yang dapat menciptakan suasana yang nyaman dan menyenangkan. Guru perlu menciptakan kondisi dan situasi yang memungkinkan siswa membentuk makna dari bahan pelajaran melalui suatu proses belajar. Alur proses belajar tidak harus berasal dari guru menuju siswa. Selain interaksi antara siswa dengan guru, proses belajar akan mencapai hasil yang optimal apabila terjadi interaksi antar siswa sehingga memungkinkan timbulnya sikap keterkaitan 
Wahyuni, I. dan Munthe, YG.: Pengaruh Model Pembelajaran Kooperatif Tipe Two Stay Two Stray (TSTS) Terhadap Hasil Belajar Siswa Pada Materi Listrik Dinamis Pada Siswa SMA.
Jurnal Pendidikan Fisika

p-ISSN 2252-732X

e-ISSN 2301-7651 untuk mengikuti kegiatan belajar mengajar secara menyeluruh.

Siswa juga bisa saling mengajar dengan sesama siswa yang lainnya. Lie (2010) menyatakan bahwa sistem pengajaran yang memberi kesempatan kepada anak didik untuk bekerja sama dengan sesama siswa dalam tugas-tugas yang terstruktur disebut sistem "pembelajaran gotong royong" atau cooperative learning. Dalam sistem ini, guru bertindak sebagai fasilitator.

Berdasarkan masalah tersebut, peneliti menerapkan salah satu model kooperatif yaitu model pembelajaran kooperatif tipe Two Stay Two Stray (TSTS). Tipe Two Stay Two Stray atau Dua Tinggal Dua Tamu memberi kesempatan kepada kelompok untuk membagikan hasil dan informasi kepada kelompok lain secara bergilir. Siswa dapat belajar dalam kelompok yang memiliki tingkat kemampuan yang berbeda.

Penelitian tentang model pembelajaran kooperatif Two Stay Two Stray sudah pernah dilakukan oleh Leona dengan judul penelitian adalah Pengaruh Penerapan Model Pembelajaran Kooperatif Tipe Two Stay Two Stray (TSTS) Terhadap Peningkatan Hasil Belajar dan Aktivitas Siswa Pada Sub Pokok Bahasan Koloid Di Kelas II Semester 2 SMA Negeri 6 Medan Tahun Ajaran 2010/2011 dan Herlina Sitorus dengan judul penelitian adalah Pengaruh Pembelajaran Kooperatif Tehnik Two Stay Two Stray (TSTS) Terhadap Hasil Belajar Siswa pada Materi Suhu dan Kalor Kelas X SMA Swasta Prayatna Medan. Berdasarkan hasil penelitian tersebut dapat disimpulkan bahwa adanya peningkatan yang signifikan hasil belajar siswa dengan menggunakan model pembelajaran kooperatif tipe Two Stay Two Stray (TSTS). Namun ada beberapa kendala yang muncul saat pelaksanaan penelitian yaitu pembagian kelompok yang memerlukan waktu banyak, adanya kelompok yang beranggotakan 5 orang dan penguasaan kelas yang kurang.

Upaya yang akan dilakukan peneliti dalam mengatasi kendala yang muncul pada peneliti sebelumnya adalah dengan membentuk kelompok yang diusahakan seoptimal mungkin dengan kemampuan yang hampir sama antar kelompok, pembagian kelompok hanya dilakukan sekali untuk beberapa pertemuan, dan peneliti akan lebih mengoptimalkan alokasi waktu dengan menentukan waktu yang diperlukan siswa pada setiap langkah pembelajaran.

Adapun tujuan penelitian ini adalah untuk mengetahui aktivitas siswa selama mengikuti pembelajaran dengan menggunakan model pembelajaran kooperatif Tipe Two Stay Two Stray pada materi pokok Listrik Dinamis di kelas X SMA Negeri 3 Tebing Tinggi T.P 2012/2013, untuk mengetahui persepsi siswa terhadap pelajaran Fisika setelah diterapkannya model pembelajaran Kooperatif Tipe Two Stay Two Stray pada materi pokok Listrik Dinamis di kelas X SMA Negeri 3 Tebing Tinggi T.P. 2012/2013, untuk mengetahui hasil belajar siswa dengan menggunakan model pembelajaran Kooperatif Tipe Two Stay Two Stray pada materi pokok Listrik Dinamis di kelas X SMA Negeri 3 Tebing Tinggi T.P 2012/2013, untuk mengetahui pengaruh model pembelajaran Kooperatif Tipe Two Stay Two Stray terhadap hasil belajar siswa pada materi pokok Listrik Dinamis di kelas X SMA Negeri 3 Tebing Tinggi T.P 2012/2013, dan untuk mengetahui hasil belajar fisika siswa yang menggunakan pembelajaran konvensional pada materi pokok Listrik Dinamis di kelas X SMA Negeri 3 Tebing Tinggi T.P 2012/2013.

\section{METODE PENELITIAN}

Penelitian ini dilaksanakan di SMA Negeri 3 Tebing Tinggi kelas X Semester II tahun Pelajaran 2012/2013. Penelitian ini akan dilakukan pada bulan Mei 2013. Populasi dalam penelitian ini adalah seluruh siswa kelas $\mathrm{X}$ SMA Negeri 3 Tebing Tinggi yang terdiri dari 9 kelas paralel. Sampel dalam penelitian ini 2 kelas yang diambil dengan menggunakan cluster random sampling yaitu satu kelas sebagai kelas eksperimen yang diajarkan dengan menggunakan model pembelajaran Kooperatif Tipe Two Stay Two Stray pada 
materi Listrik Dinamis. Sedangkan satu kelas lainnya sebagai kelas kontrol yaitu kelas yang diajarkan dengan menggunakan model pembelajaran Konvensional pada materi Listrik Dinamis.

Pada penelitian ini menggunakan dua variabel yakni Variabel bebas dan variabel terikat. Variabel bebas adalah model pembelajaran yang terdiri atas model pembelajaran Kooperatif Tipe Two Stay Two Stray dan model pembelajaran Konvensional. Variabel terikat dalam penelitian ini adalah hasil belajar siswa dalam pembelajaran pada materi Listrik Dinamis. Penelitian ini termasuk jenis penelitian Quasi Eksperiment yaitu merupakan penelitian yang dimaksudkan untuk mengetahui ada tidaknya pengaruh dari sesuatu yang dikenakan pada subjek yaitu siswa.

Penelitian ini melibatkan dua kelas yaitu kelas eksperimen dan kelas kontrol, dimana kedua kelas ini diberikan perlakuan yang berbeda. Untuk mengetahui hasil belajar siswa yang diperoleh dengan dua perlakuan tersebut maka siswa diberikan tes sebanyak dua kali yaitu sebelum perlakuan dan sesudah perlakuan. Desain ini dirancang sebagai berikut:

Tabel 1. Rancangan Penelitian

\begin{tabular}{lccc}
\hline \multicolumn{1}{c}{ Kelas } & $\begin{array}{c}\text { Pre } \\
\text { Tes }\end{array}$ & Perlakuan & $\begin{array}{c}\text { Pos } \\
\text { Tes }\end{array}$ \\
\hline Eksperimen & $\mathrm{T}_{1}$ & $\mathrm{X}$ & $\mathrm{T}_{2}$ \\
\hline Kontrol & $\mathrm{T}_{1}$ & $\mathrm{Y}$ & $\mathrm{T}_{2}$ \\
\hline $\begin{array}{l}\text { Dengan: } \\
\mathrm{T}_{1}=\text { Pretest pada kelas eksperimen dan kelas } \\
\text { kontrol }\end{array}$ \\
$\mathrm{T}_{2}=\begin{array}{l}\text { Postest pada kelas eksperimen dan kelas } \\
\text { kontrol }\end{array}$ \\
$\mathrm{X}=\begin{array}{c}\text { Perlakuan yang diberikan kepada kelas } \\
\text { eksperimen }\end{array}$ \\
$\mathrm{Y}=\begin{array}{l}\text { Perlakuan yang deberikan kepada kelas } \\
\text { kontrol }\end{array}$
\end{tabular}

Untuk menguji hipotesis yang dikemukakan, dilaksanakan dengan membandingkan rata-rata skor hasil belajar yang dicapai baik kelompok eksperimen dengan kelompok kontrol. Data yang diperoleh ditabulasikan kemudian dicari rata-ratanya. Sebelum dilakukan penganalisisan data, terlebih dahulu ditentukan skor masing-masing kelompok sampel lalu dilakukan pengolahan data dengan Menghitung nilai rata-rata dan simpangan baku, Uji Normalitas, Uji Homogenitas, Pengujian Hipotesis (Uji t) dengan Uji kesamaan rata-rata pretes (uji t dua pihak).

Dari hasil perhitungan uji-t dua pihak diperoleh $\mathrm{t}_{\text {hitung }}=1,322$. Pada taraf signifikan $\alpha=0,05$ dan $\mathrm{dk}=60$ diperoleh $\mathrm{t}_{\text {tabel }}=2,012$. Dimana kriteria pengujiannya adalah $H_{a}$ diterima jika $-\mathrm{t}_{\text {tabel }}<\mathrm{t}_{\text {hitung }}<\mathrm{t}_{\text {tabel }}$ maka yaitu yaitu $-2,012<1,322<2,012$,sehingga dapat diperoleh kesimpulan bahwa antara kelas eksperimen dan kelas kontrol mempunyai kemampuan awal yang sama. Untuk pengujian hipotesis kemampuan postes dilakukan dengan uji beda $\mathrm{t}$ yaitu membedakan rata-rata hasil postes siswa kelas eksperimen dan kelas kontrol dengan tujuan untuk mengetahui perbedaan hasil belajar siswa yang diajar dengan model pembelajaran konvensional dan yang diajar dengan model pembelajaran Kooperatif Tipe TSTS pada Materi Listrik Dinamis di kelas X SMA Negeri 3 Tebing Tinggi T.P 2012/2013.

Hipotesis yang diuji berbentuk:

$\mathrm{H}_{o}: \mu_{1} \leq \mu_{2}$

$\mathrm{Ha}: \mu_{1}>\mu_{2}$

$\mu_{1}=$ adalah skor rata-rata hasil belajar kelas eksperimen

$\mu_{2}=$ adalah skor rata-rata hasil belajar kelas control

Dari hasil perhitungan uji-t satu pihak diperoleh $t_{\text {hitung }}=2,326$. Pada taraf signifikan $\alpha=0,05$ dan $\mathrm{dk}=60$ diperoleh $\mathrm{t}_{\text {tabel }}=2,006$. Dimana kriteria pengujiannya adalah $H_{a}$ diterima jika $t>t_{1 / 2-\alpha}(2,326>2,006)$, maka $H_{a}$ diterima dan $\mathrm{H}_{\mathrm{O}}$ ditolak sehingga dapat disimpulkan bahwa terdapat perbedaan akibat pengaruh yang signifikan pada hasil belajar siswa yang diajar dengan Model Pembelajaran Kooperatif Tipe Two Stay Two Stray. 


\section{HASIL PENELITIAN DAN PEMBAHASAN}

Hasil penelitian menunjukkan bahwa adanya pergaruh yang signifikan antara model pembelajaran Kooperatif Tipe Two Stay Two Stray dan pembelajaran Konvensional terhadap hasil belajar Fisika pada materi Listrik Dinamis di SMA Negeri 3 Tebing Tinggi. Hal ini dapat diperlihatkan melalui data hasil penelitian yang diperolah dimana nilai rata-rata postes pada kelas eksperiman adalah 72,30 dengan standar 8,4 sedangkan nilai rata-rata postes pada kelas kontrol adalah 66,6 dengan standar deviasi 9,9. Dalam hal ini terdapat perbedaan nilai rata-rata postes kelas eksperimen dengan kelas kontrol sebesar 5,70.

Tabel 2. Distribusi Nilai Pretes Kelas

Eksperimen dan Pretes Kelas Kontrol

\begin{tabular}{|c|c|c|c|c|c|c|c|}
\hline \multicolumn{4}{|c|}{ Kelas Eksperimen } & \multicolumn{4}{|c|}{ Kelas Kontrol } \\
\hline $\begin{array}{l}\mathrm{N} \\
\mathrm{O}\end{array}$ & $\begin{array}{l}\mathrm{Ni} \\
\text { lai }\end{array}$ & frek & $\begin{array}{l}\text { Rata- } \\
\text { rata }\end{array}$ & $\begin{array}{l}\mathrm{N} \\
\mathrm{O}\end{array}$ & $\begin{array}{l}\mathrm{Ni} \\
\text { lai }\end{array}$ & Frek & $\begin{array}{l}\text { Rata- } \\
\text { rata }\end{array}$ \\
\hline 1 & 20 & 2 & \multirow{10}{*}{36,30} & 1 & 10 & 1 & \multirow{10}{*}{27,90} \\
\hline 2 & 25 & 5 & & 2 & 15 & 1 & \\
\hline 3 & 30 & 6 & & 3 & 20 & 6 & \\
\hline 4 & 35 & 3 & & 4 & 25 & 6 & \\
\hline 5 & 40 & 3 & & 5 & 30 & 6 & \\
\hline 6 & 45 & 4 & & 6 & 35 & 5 & \\
\hline 7 & 50 & 3 & & 7 & 40 & 1 & \\
\hline 8 & 55 & 1 & & 8 & 45 & 2 & \\
\hline 9 & 60 & 1 & & \multirow{2}{*}{\multicolumn{2}{|c|}{$\Sigma$}} & \multirow{2}{*}{28} & \\
\hline & $\Sigma$ & 28 & & & & & \\
\hline
\end{tabular}

Tabel 3. Distribusi Nilai Postes Kelas Eksperimen dan Kelas Kontrol

\begin{tabular}{|c|c|c|c|c|c|c|c|}
\hline \multicolumn{4}{|c|}{ Kelas Eksperimen } & \multicolumn{4}{|c|}{ Kelas Kontrol } \\
\hline No & $\begin{array}{l}\mathrm{Ni} \\
\text { lai }\end{array}$ & frek & $\begin{array}{l}\text { Rata- } \\
\text { Rata }\end{array}$ & No & $\begin{array}{l}\mathrm{Ni} \\
\text { lai }\end{array}$ & frek & $\begin{array}{l}\text { Rata- } \\
\text { rata }\end{array}$ \\
\hline 1 & 55 & 1 & \multirow{12}{*}{72,30} & 1 & 35 & 1 & \multirow{12}{*}{66,60} \\
\hline 2 & 60 & 1 & & 2 & 40 & 0 & \\
\hline 3 & 65 & 7 & & 3 & 45 & 0 & \\
\hline 4 & 70 & 6 & & 4 & 50 & 1 & \\
\hline 5 & 75 & 8 & & 5 & 55 & 2 & \\
\hline 6 & 80 & 3 & & 6 & 60 & 2 & \\
\hline 7 & 85 & 1 & & 7 & 65 & 8 & \\
\hline 8 & 90 & 2 & & 8 & 70 & 8 & \\
\hline & \multirow{4}{*}{$\Sigma$} & \multirow{4}{*}{28} & & 9 & 75 & 3 & \\
\hline & & & & 10 & 80 & 2 & \\
\hline & & & & 11 & 85 & 1 & \\
\hline & & & & \multicolumn{2}{|c|}{$\Sigma$} & 28 & \\
\hline
\end{tabular}

Tabel 4. Ringkasan Perhitungan Uji Hipotesis Kemampuan Pretes

\begin{tabular}{lcccc}
\hline Data Kelas & $\begin{array}{l}\text { Rata- } \\
\text { rata }\end{array}$ & $\mathrm{t}_{\text {hitung }}$ & $\mathrm{t}_{\text {tabel }}$ & $\begin{array}{c}\text { Kesim } \\
\text { pulan }\end{array}$ \\
\hline $\begin{array}{l}\text { Pretes kelas } \\
\text { Eskperimen }\end{array}$ & 36,3 & & & \\
$\begin{array}{l}\text { Pretes kelas } \\
\text { Kontrol }\end{array}$ & 27,9 & 1,322 & 2,012 & $\begin{array}{c}\text { Ho } \\
\text { diterima }\end{array}$ \\
\hline
\end{tabular}

Tabel 5. Ringkasan Perhitungan Uji t

\begin{tabular}{cccccl}
\hline $\mathrm{N}$ & Sampel & $\begin{array}{c}\text { Rata- } \\
\text { rata }\end{array}$ & $\mathrm{t}_{\text {hitung }}$ & $\mathrm{t}_{\text {tabel }}$ & Kesimpulan \\
\hline 1 & Eksperimen & 72,3 & & & $\begin{array}{l}\text { Ada } \\
\text { perbedaan } \\
2\end{array}$ \\
Kontrol & 66,6 & 2,326 & 2,006 & $\begin{array}{l}\text { yang } \\
\text { signifikan }\end{array}$ \\
\hline
\end{tabular}

Aktivitas siswa selama proses pembelajaran tidak dapat mencapai $100 \%$, karena keterlibatan siswa belum maksimal pada saat pembelajaran model pembelajaran Kooperatif Tipe Two Stay Two Stray. Pada tabel observasi aktivitas siswa pada kelas eksperimen dapat dilihat adanya peningkatan aktivitas yaitu pada pertemuan I rata-rata aktivitas siswa kelas eksperimen adalah 53,1, pada pertemuan II 57,87, pertemuan II 79,5 sedangkan pada pertemuan IV meningkat menjadi 85,23. Aktivitas siswa yang paling tinggi adalah dapat dilihat pada pertemuan ke-4, hal ini disebabkan karena siswa sudah terbiasa dengan kegiatan pembelajaran sehingga siswa termotivasi untuk berpartisipasi dalam kegiatan pembelajaran.

Pada akhir pertemuan, siswa diberikan angket persepsi 7,14\% siswa memiliki persepsi tinggi terhadap pelajaran fisika dan $92,85 \%$ memiliki persepsi sedang. Berdasarkan data tersebut, siswa yang memiliki persepsi tinggi memperoleh hasil belajar yang baik. Sehingga dapat disimpulkan bahwa persepsi belajar siswa berhubungan dengan hasil belajar yang diperoleh siswa.

Dari hasil ini dapat disimpulkan bahwa model pembelajaran Kooperatif Tipe Two Stay Two Stray dapat meningkatkan hasil belajar fisika siswa. Adanya peningkatan hasil belajar tersebut disebabkan oleh kelebihan model pembelajaran Kooperatif Tipe Two Stay Two Stray yang dapat memotivasi siswa untuk 
Wahyuni, I. dan Munthe, YG.: Pengaruh Model Pembelajaran Kooperatif Tipe Two Stay Two Stray (TSTS) Terhadap Hasil Belajar Siswa Pada Materi Listrik Dinamis Pada Siswa SMA.

saling membantu dalam dan antar kelompok. Pada saat proses pembelajar dapat terlihat adanya terjadi interaksi antar siswa sehingga memungkinkan timbulnya sikap partisipasi untuk mengikuti kegiatan belajar mengajar secara menyeluruh.

\section{SIMPULAN}

Berdasarkan hasil analisis data dan pembahasan maka dapat disimpulkan bahwa hasil observasi aktivitas belajar siswa setelah menerapkan model Kooperatif Tipe Two Stay Two Stray 28,50\% kategori amat baik, 46,42\% kategori baik, dan 25,00\% kategori cukup baik. Melalui data observasi aktivitas belajar siswa untuk model tersebut dapat disimpulkan bahwa rata-rata siswa yang aktif dalam belajar memperoleh hasil belajar yang lebih tinggi dibandingkan siswa yang kurang aktif pada saat pembelajaran. Persepsi siswa terhadap pelajaran Fisika setelah diterapkannya model pembelajaran Kooperatif Tipe Two Stay Two Stray pada materi pokok Listrik Dinamis 92,85\% kategori sedang dan 7,14\% kategori tinggi. Berdasarkan hasil angket dapat disimpulkan bahwa siswa memiliki persepsi tinggi terhadap pelajaran Fisika memperoleh hasil belajar yang baik.

Hasil belajar siswa yang diberi pembelajaran dengan model pembelajaran Kooperatif Tipe Two Stay Two Stray pada materi pokok Listrik Dinamis di kelas X SMA Negeri 3
Tebing Tinggi T.P 2012/2013 sebelum diberikan perlakuan rata-rata pretes sebesar 36,30 dan setelah diberikan perlakuan rata-rata postes siswa sebesar 72,36.

Hasil belajar siswa yang diberi pembelajaran dengan pendekatan konvensional pada pada materi pokok Listrik Dinamis di kelas X SMA Swasta Negeri 3 Tebing Tinggi T.P 2012/2013 sebelum diberikan perlakuan rata-rata pretes sebesar 27,90 dan setelah diberikan perlakuan, rata-rata postes siswa sebesar 66,60. Ada perbedaan akibat pengaruh yang signifikan pada hasil belajar dengan menggunakan model pembelajarn Koperatif Tipe Two Stay Two Stray pada materi Listrik Dinamis di kelas X SMA Negeri 3 Tebing Tinggi T.P 2012/2013

\section{DAFTAR PUSTAKA}

Istarani. 2012. 58 Model Pembelajaran Inovatif. Medan: Media Persada.

Lie, A. 2010. Cooperative-Learning. Jakarta: PT.Grasindo.

Leona. 2011. Pengaruh Penerapan Model Pembelajaran Kooperatif Tipe Two Stay Two Stray (TS-TS) Terhadap Peningkatan Hasil Belajar dan Aktivitas Siswa Pada Sub Pokok Bahasan Koloid Di Kelas II Semester 2 SMA Negeri 6 Medan Tahun Ajaran 2010/2011. Medan: Unimed. 